\title{
Correction to: Announcing the Shape Memory and Superelasticity 2019 Editor's Choice Selections
}

\author{
Huseyin Sehitoglu ${ }^{1}$
}

Published online: 31 July 2020

(C) ASM International 2020

\section{Correction to: Shap. Mem. Superelasticity https://doi.org/10.1007/s40830-020-00292-0}

This correction is to correct the spelling of an author referenced in the article. The reference should appear as:
Bonsignore C, Shamimi A, Duerig T (2019) The role of parent phase compliance on the fatigue lifetime of $\mathrm{Ni}-\mathrm{Ti}$. Shape Mem Superelast 5:407-414

Publisher's Note Springer Nature remains neutral with regard to jurisdictional claims in published maps and institutional affiliations.

The original article can be found online at https:// doi.org/10.1007/s40830-020-00292-0.

$\triangle$ Huseyin Sehitoglu huseyin@illinois.edu

1 University of Illinois At Urbana-Champaign, Champaign, IL, USA 